\title{
Wykorzystywanie komputerowych symulacji przepływu w projektowaniu separatora cyklonowego dla trakcyjnych ukladów uzdatniania sprężonego powietrza
}

\begin{abstract}
Większość separatorów cyklonowych stosowanych w kolejnictwie to konstrukcje przemystowe, jedynie przystosowywane do specyficznych warunków pracy jakimi sq warunki trakcyjne, które sq znacznie bardziej wymagajace. W niniejszym artykule przedstawiono proces projektowania separatora cyklonowego spetniajacego wymagania trakcyjnych układów uzdatniania sprężonego powietrza, z wykorzystaniem programu CAD z naktadka CAE do symulacji przeptywu. Projekt zrealizowano od określenia wymagań dla trakcyjnego separatora cyklonowego, przez koncepcje konstrukcji i działania, do utworzenia modeli symulacyjnych. Symulacje przeprowadzano dla różnie konfigurowanych elementów odpowiedzialnych za optymalne realizowanie funkcji separowania zanieczyszczen. Na podstawie przeprowadzonych symulacji dla różnych wariantów konstrukcji wybrano do wykonania jedno z rozwiazań.

Podjęte działania miały na celu zbudowanie prototypu, przeprowadzenie na nim badań, a następnie wdrożenie opracowanego rozwiazania do produkcji i do eksploatacji w trakcyjnych układach uzdatniania sprężonego powietrza.
\end{abstract}

\section{WSTĘP}

Nowoczesne projektowanie jest ściśle powiązane $\mathrm{z}$ użyciem komputerowego oprogramowania. Cała grupa programów komputerowych wspomagających prace projektanta dzieli się na programy wspomagające: projektowanie (CAD), obliczenia (CAE) oraz wytwarzanie (CAM) [2]. Do opracowania trakcyjnego separatora cyklonowego, będącego przedmiotem niniejszego opracowania, wykorzystano pierwsze dwa typy programów. Komputerowe wspomaganie projektowania CAD (Computer Aided Design) jest to obecnie najpopularniejsze typ oprogramowania wspomagający projektowanie. Służy ono do tworzenia konstrukcji poprzez ich modelowanie trójwymiarowe zapisywane cyfrowo oraz wykonywania dokumentacji płaskiej, wykonawczej [2]. Komputerowe wspomaganie obliczeń CAE (Computer Aided Engineering) jest to wspomaganie obliczeń konstrukcji i symulacji jej działania za pomocą specjalistycznego oprogramowania komputerowego [2]. Komputerowe wspomaganie projektowania i obliczeń ma przede wszystkim wspomagać pracę projektanta poprzez [2]:

- skrócenie czasu potrzebnego do projektowania, a co za tym idzie, do podjęcia produkcji seryjnej produktu, co skutkuje istotnym obniżeniem kosztów,

- minimalizację ilości prototypów oraz przeprowadzanych na nich badań,
- poprawę jakości wyrobu poprzez umożliwienie optymalizacji rozwiązań szczegółowych, które często są trudne do zrealizowania $\mathrm{w}$ procesie badawczym wykonanego już prototypu.

Programy CAD/CAE w znaczący sposób wpływają na przyspieszenie procesu projektowania zwłaszcza bardzo skomplikowanych konstrukcji, umożliwiając szybsze wykrycie błędów powstałych podczas projektowania czy wstępną optymalizację konstrukcji na etapie przed produkcyjnym. Zalet wykorzystywania tego typu oprogramowania jest bardzo dużo, jednakże w niniejszym artykule skupiono się na przedstawieniu aspektu wspomagania optymalizacji wyrobu na przykładzie projektu trakcyjnego separatora cyklonowego z rodziny trakcyjnych separatorów cyklonowych sprężonego powietrza $\mathrm{z}$ wykorzystaniem nakładki CAE FloXpress programu CAD Solid Works 2012. Nakładka ta umożliwia symulację przepływu cieczy przez zamodelowany trójwymiarowo obiekt $\mathrm{w}$ programie Solid Works. Poprzez rodzinę separatorów cyklonowych rozumie się separatory dla układów o różnej wydajności. W artykule przedstawiono pracę nad separatorem do układów lokomotywowych, o wydajności mieszczącej się $\mathrm{w}$ zakresie od $70 \mathrm{~m}^{3} / \mathrm{h}$ do $200 \mathrm{~m}^{3} / \mathrm{h}$. 


\section{OPIS ŚRODOWISKA PRACY}

Program Solid Works jest programem typu CAD. Umożliwia modelowanie trójwymiarowych obiektów, wykonywanie na nich operacji oraz tworzenie rzutów płaskich zamodelowanych brył czyli tworzenie dokumentacji. Umożliwia budowanie złożeń składających się nawet z kilkunastu tysięcy elementów. Posiada własne biblioteki elementów znormalizowanych. Dzięki rozwiniętym dodatkom można prowadzić w nim także działania z zakresu CAE, poprzez dodatki takie jak:

- SolidWorks Motion - służący do analizy ruchu i układów kinematycznych

- SolidWorks Simulation - służący do analiz metodą elementów skończonych

- SolidWorks Flow Simulation - służący do analizy dynamicznej przepływu płynów

Do przeprowadzenia symulacji przepływu sprężonego powietrza przez separator cyklonowy użyto dodatku FloXpress będącego nieco uproszczoną wersją dodatku Flow Simulation. Dodatek ten umożliwia przeprowadzenie symulacji przepływu przez zamodelowany obiekt, poprzez zadanie takich parametrów jak:

- rodzaj płynu - poprzez wskazanie czy płynem dla którego prowadzona będzie symulacja ma być woda czy powietrze

- warunki wejściowe (wlotowe) - poprzez wskazanie powierzchni wejścia płynu do układu oraz określenie jednej z trzech wartości: ciśnienia na wejściu, objętościowego natężenia przepływu lub masowego natężenia przepływu,

- warunki wyjściowe (wylotowe) - poprzez wskazanie powierzchni wyjścia płynu z układu oraz określenie jednej z dwóch wartości: ciśnienia na wyjściu lub objętościowego natężenia przepływu.

Wyniki przeprowadzonej symulacji przedstawiane są przez program $\mathrm{w}$ formie graficznej poprzez pokazanie strug przepływającego płynu w postaci linii lub kulek w różnych kolorach, którym to kolorom przyporządkowane są odpowiednie wartości prędkości przepływu. Interpretację wyników przeprowadzano na podstawie oceny prędkości przepływu, równomierności rozłożenia oraz ukształtowania strug płynu przedstawionych przez program.

\section{PRZEBIEG PRAC}

Podjęte prace miały na celu stworzenie separatora cyklonowego, odpowiedniego dla zastosowania go w warunkach trakcyjnych. Warunki trakcyjne są warunkami bardzo specyficznymi, wymagają wysokiej niezawodności działania, pracy $\mathrm{w}$ warunkach dużej nieczystości otoczenia, odporności na drgania oraz odporności na tworzenie się niedrożności kanałów spustu zebranego kondensatu odizolowanego ze sprężonego powietrza. Dodatkowo praca w takich warunkach wymaga od urządzenia poprawnego działania w zakresie temperatur od $-40^{\circ} \mathrm{C}$ do $+50^{\circ} \mathrm{C}$, a dla lokomotyw spalinowych do nawet $+70^{\circ} \mathrm{C}$. Ze względu na tak duży zakres temperatury pracy, który obejmuje bardzo niskie temperatury warunki trakcyjne wymagaja zapewnienie podgrzewania i ocieplenia niektórych części separatora, umożliwiając jego prace w bardzo niskich temperaturach. Jest to szczególnie istotne ze względu na separację głównie wody, która niesie niebezpieczeństwo zablokowania ruchomych części poprzez zamarzanie. Dodatkowo urządzenie to powinno być możliwie małe, odporne na uszkodzenia zewnętrzne, proste $\mathrm{w}$ obsłudze oraz nie wymagające dużej przestrzeni serwisowej, a co za tym idzie - zabudowy.

W układach trakcyjnych do których projektowano opisywany separator, zabudowany jest on zwyczajowo za chłodnica powietrza. W takich warunkach głównymi zanieczyszczeniami sprężonego powietrza są cząsteczki wody i oleju. Woda wykrapla się z powietrza podczas jego chłodzenia w chłodnicy oraz w układzie doprowadzającym to powietrze do separatora. Można zatem $\mathrm{z}$ dużym prawdopodobieństwem założyć, iż drobiny wody, które separator będzie miał za zadanie odseparować, będą dość różnej wielkości, gdyż będą to kropelki porywane ze ścianek układu przez przepływające powietrze oraz niewielkie cząsteczki wody i oleju transportowane przez sprężone powietrze. Odseparowane cząstki powinny zbierać się w zbiorniku separatora i być regularnie stamtąd usuwane. Upust zebranego w zbiorniku separatora kondensatu powinien odbywać się samoczynnie, a upuszczony kondensat powinien mieć możliwość odprowadzania go do zbiornika kondensatu zabudowanego na pojeździe.

Projektowanie rozpoczęto od koncepcji budowy i działania separatora. Należało wstępnie przewidzieć sposób wprowadzenia strugi w ruch wirowy, mający na celu oddzielenie cząstek poprzez działanie siły odśrodkowej oraz zapewnienie odpowiednio dużej prędkości strumienia powietrza przepływającego wirowo przez separator. Koncepcja budowy i działania obejmowała także sterowanie spustem kondensatu. Następnie wykorzystując oprogramowania CAD, przystapiono do budowy modelu trójwymiarowego opartego o przyjętą koncepcję.

Początkowo stworzony model odwzorowywał przede wszystkim jedynie podstawową zasadę działania separatora wg przyjętej koncepcji, czyli uwzględniając jedynie elementy istotne $\mathrm{z}$ punktu widzenia spełniania przez niego funkcji separacji drobin wody i cząstek stałych ze sprężonego powietrza. Kanał wlotowy znajdował się po prawej stronie płaszczyzny 
czołowej głowicy, w dolnej jej części. Natomiast kanał wylotowy znajdował się na przeciwnej płaszczyźnie, powyżej osi kanału wlotowego, w osi podłużnej głowicy. Używając powstałego modelu przeprowadzono pierwsze symulacje przepływu. Symulacje te przeprowadzono dla środkowej wartości natężenia przepływu (z deklarowanego zakresu $70-200 \mathrm{~m}^{3} / \mathrm{h}$ ). Widok wyników symulacji przedstawiono na rysunku 1 .

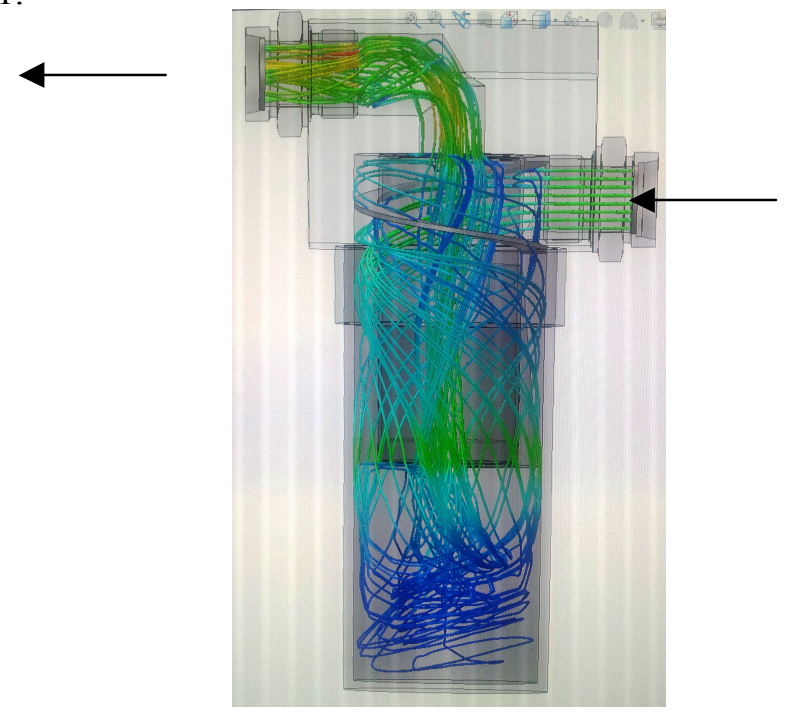

Rys. 1 - Widok przebiegu jednej z pierwszych symulacji przeprowadzonych na wstępnym modelu.

Ze względu na konieczność uwzględnienia możliwości łączenia separatora $\mathrm{z}$ filtrami i formowania ich w baterie urządzeń uzdatniania powietrza, model ten gruntownie przebudowano. W celu umożliwienia takiego łączenia wprowadzono symetryczność wlotu i wylotu powietrza w głowicy separatora, umieszczając je na równej wysokości w osi symetrii podłużnej głowicy separatora. Spowodowało to konieczność wprowadzenia nowego elementu powodującego ruch wirowy powietrza w separatorze. Wyniki przeprowadzonej symulacji tak przebudowanego modelu przedstawiono na rysunku 2.

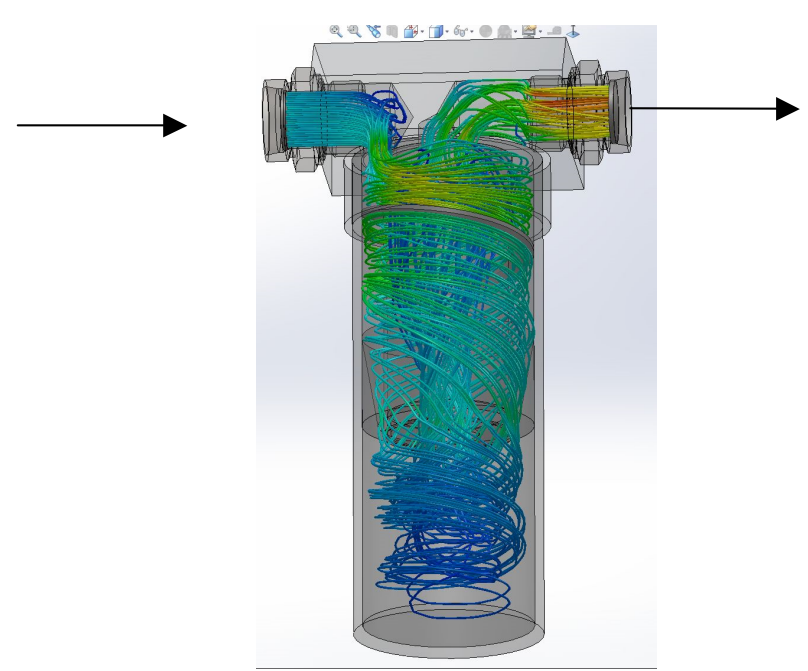

Rys. 2 - Widok wyników symulacji przeprowadzonej na kolejnym modelu ze zmodyfikowaną głowicą separatora
Analiza uzyskanych wyników wykazała, że czas przepływu sprężonego powietrza w ruchu wirowym jest zbyt mały. Dodatkowo ruch wirowy strugi powietrza oceniono jako odbywający się po okręgu o zbyt dużej średnicy. Również wyznaczone przez program wartości prędkości przepływu w kluczowych miejscach $\mathrm{z}$ punktu widzenia separacji cząstek były małe i wynosiły zaledwie około $10 \mathrm{~m} / \mathrm{s}$. Analizując wyniki przedstawione na rysunku 1 i 2 zaobserwowano jeszcze jedno niekorzystne zjawisko, polegające na zbyt niskim (ograniczonym dnem zbiornika) wirowaniu strugi. $Z$ tego powodu podjęto decyzję o zaprojektowaniu dodatkowej przegrody.

$\mathrm{Na}$ podstawie przeprowadzonych symulacji dokonano następujących zmian:

- wprowadzono dodatkowe kierownice powietrza, zmodyfikowano ich kształt oraz zmieniono ich położenie,

- w odpowiednich miejscach wprowadzono specjalne przewężenia i powiększenia przekrojów kanałów którymi przepływa sprężone powietrze,

- wprowadzono elementy o kształtach wspomagających separację poprzez zwiększenie prędkości przepływu oraz zmianę jego kierunku,

- $\quad$ wprowadzono specjalną przegrodę oddzielająca zebrany kondensat od strugi wirującego powietrza.

Otrzymany po wprowadzeniu powyższych zmian model ponownie poddano wielokrotnym symulacjom, wprowadzając niewielkie korekty położenia i kształtu elementów wewnętrznych separatora.

Przebieg symulacji kolejnej, a zarazem końcowej wersji separatora cyklonowego przedstawiono na rysunku 3.

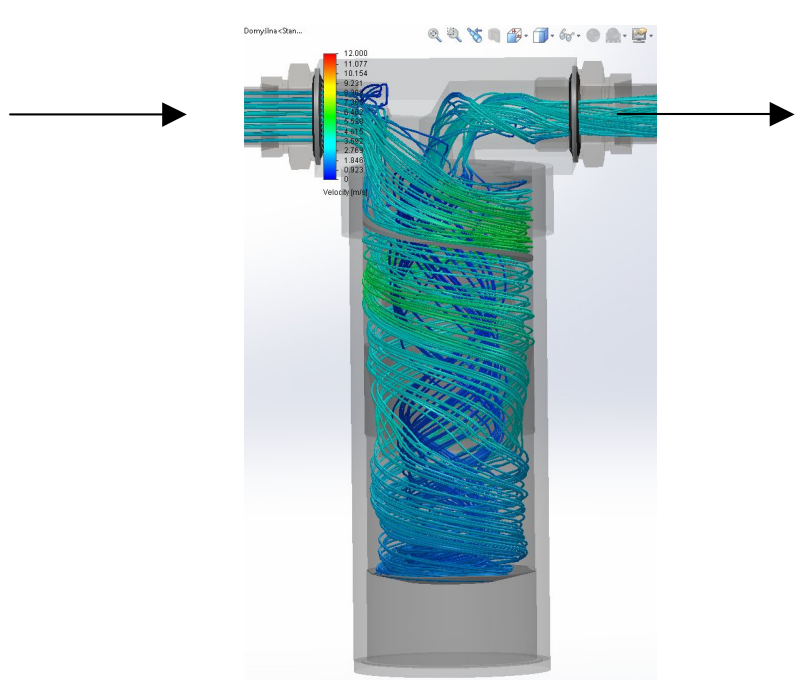

Rys. 3 - Widok wyników symulacji przeprowadzonej na kolejnym modelu separatora $\mathrm{z}$ wprowadzonymi zmianami 
Symulacja tej wersji modelu wykazała zadowalającą, oczekiwaną prędkość i równomierność rozkładu strugi powietrza. Zastosowane przewężenia oraz kierownice spowodowały właściwe zwiększenie prędkości powietrza przepływającego przez separator i utrzymanie jej na wysokim poziomie, podnosząc tym samym skuteczność separacji poprzez utrzymywanie się zwiększonej siły odśrodkowej działającej na separowane cząstki. Należy zwrócić uwagę na fakt iż wysoka prędkość przepływu nie jest pożądana na całej drodze która pokonuje powietrze $\mathrm{w}$ separatorze. Sa miejsca w których została ona celowo obniżona przez znaczące zwiększenie powierzchni przekroju kanału w celu skuteczniejszego oddzielenia zanieczyszczeń od powietrza opuszczającego separator.

\section{PODSUMOWANIE I WNIOSKI}

Opisane w rozdziale 3 przykłady były głównymi etapami symulacji istotnie różnych modeli. W każdym etapie wykonano wiele symulacji badanych modeli z niewielkimi zmianami $\mathrm{w}$ zakresie kształtu $\mathrm{i}$ wymiarów detali wewnętrznych separatora cyklonowego, mających na celu poszukiwanie optymalnego rozwiązania spełniającego założone oczekiwania. Zanim osiagnięto zadowalające wyniki badań wykonano kilkadziesiąt symulacji.

Po przeprowadzeniu badań symulacyjnych z użyciem oprogramowania CAD SolidWorks $\mathrm{z}$ dodatkiem CAE FloXpress, opracowano dokumentację wykonawczą trakcyjnego separatora cyklonowego i przekazano ją do wyprodukowania pierwszego prototypu. Widok modelu stworzonego w programie CAD oraz widok gotowego, wyprodukowanego produktu przedstawiono na rysunku 4.

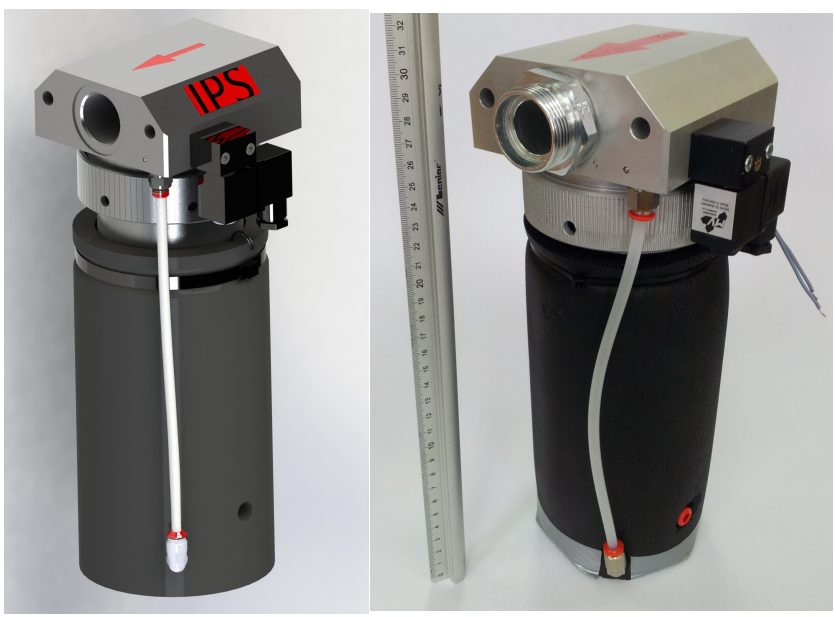

Rys. 4 - Widok modelu stworzonego w programie SolidWorks oraz wyprodukowanego separatora.

Kolejnym etapem prac nad trakcyjnym separatorem cyklonowym będzie przeprowadzenia badań stanowiskowych, mających na celu weryfikację skuteczności przyjętego rozwiązania. Zakładając poprawnie dobrane parametry wejściowe na podstawie których wykonywano obliczenia za pomocą programu, przepływ sprężonego powietrza przez separator powinien wygląać w sposób zbliżony do przedstawionego na rysunku trzecim. Należy jednak pamiętać że podczas wykonywania obliczeń program FloXpress nie uwzględnia drobnych szczegółów konstrukcji, tzn. takich obiektów jak na przykład spoiny między łączonymi częściami. Dodatkowo przeprowadzone symulacje nie uwzględniają zachowania się cząstek wody, pary wodnej lub zanieczyszczeń stałych w przepływającej strudze powietrza. Dotyczą jedynie przepływu strugi powietrza idealnie suchego, nie uwzględniając zachowania się cząstek wody, pary wodnej lub zanieczyszczeń stałych.

Dzięki przeprowadzonym symulacjom wykorzystującym oprogramowanie CAD oraz CAE konstruktor miał możliwość dokładnego przeanalizowania konstrukcji przed przekazaniem jej do produkcji. Tylko w opisywanym przykładzie projektu separatora pozwoliło to zaoszczędzić czas, materiał i pieniądze które potrzebne były by na wykonanie co najmniej kilku prototypów poprzedzających wyprodukowanie wersji do badań.

\section{Bibliografia}

[1] Zajqczkowski J.: Odpylanie w przemyśle, Arkady, Warszawa 1971.

[2] Bis J., Markiewicz R.: Komputerowe wspomaganie projektowania CAD, Rea, Warszawa 2008.

[3] Praca zbiorowa pod redakcja Branowskiego B.: Zagadnienia konstruowania maszyn $z$ wykorzystaniem CAD, Wydawnictwo Politechniki Poznańskiej, Poznań 1994.

[4] Mieszkowski A. Zwiększenie skuteczności odpylania cyklonów, Czasopismo techniczne, Wydawnictwo Politechniki Krakowskiej.

[5] Goliwas D., Jakubowski T., Uzdatnianie sprężonego powietrza w pojazdach trakcyjnych, Pojazdy Szynowe 4/2007.

[6] Technika sprężonego powietrza-poradnik, Wydanie 7, Atlas Copco Airpower NV.

[7] Klimawent, Urzadzenia odpylajace Tom I - katalog, Wydanie 7, Wydawnictwo Przemystu Maszynowego, Warszawa 1978 